\title{
UPAYA MENINGKATKAN HASIL BELAJAR IPA DENGAN MENGGUNAKAN MODEL PEMBELAJARAN ARTIKULASI BERBANTUAN MEDIA VISUAL PADA PESERTA DIDIK KELAS IV SDN 5 PANARUNG PALANGKARAYA TAHUN PELAJARAN 2017/2018
}

\author{
Oleh : Metri Satriani*, Drs. Ramli, M.Pd
}

\begin{abstract}
ABSTRAK
Penelitian ini bertujuan Untuk mengetahui aktifitas belajar IPA peserta didik kelas IV SDN 5 Panarung dengan menerapakan model artikulasi berbantuan media visual serta peningkatan hasil belajar IPA peserta didik kelas IV SDN 5 Panarung dengan menerapkan model artikulasi berbantuan media visual pada materi dampak pengambilan bahan alam terhadap pelestarian lingkungan di kelas IV SDN 5 Panarung Palangkaraya. Jenis dalam penelitian ini adalah menggunakan jenis Penelitian Tindakan Kelas (PTK). Adapun yang menjadi subjek penelitian ini adalah peserta didik kelas IV SDN 5 Panarung yang berjumlah 27 orang peserta didik. Instrument yang digunakan dalam penelitian ini berupa lembar observasi dan soal tes hasil belajar berupa pilihan ganda. Teknik analisis data yang digunakan adalah secara kualitatif dan kuantitatif. Dari hasil penelitian disimpulkan bahwa: (1) Aktivitas belajar peserta didik terlihat aktif dalam pemebelajaran IPA pada penerapan model artikulasi berbantuan media visual. Peserta didik berperan aktif selama proses pembelajaran pada siklus I. Adapun hasil pengamatan aktivitas peserta didik yaitu 3,52 dengan kriteria sangat aktif, dan (2) Ada peningkatan hasil belajar peserta didik setelah penerapan model artikulasi berbantuan media visual. Hal ini ditunjukan dengan hasil belajar yang dilihat melalui skor rata-rata kelas pada siklus I yaitu 79 dengan kriteria tercapai dan memenuhi KKM 70 , mencapai persentase ketuntasan belajar peserta didik secara klasikal yaitu $100 \%$, dengan ketuntasan klasikal $85 \%$.
\end{abstract}

\section{Kata Kunci : Model Pembelajaran Artikulasi, Visual dan Hasil Belajar IPA.}

\begin{abstract}
This study aims to find out the science learning activities of fourth grade students of SDN 5 Panarung by applying the articulation model assisted by visual media and improving the learning outcomes of science students of fourth grade SDN 5 Panarung by applying an articulation model assisted by visual media on the material impact of natural materials on environmental conservation in the fourth grade of SDN 5 Panarung Palangkaraya. The type in this study was to use the type of Classroom Action Research (CAR). As for the subjects of this study were the fourth grade students of SDN 5
\end{abstract}


Panarung which numbered 27 students. The instrument used in this study was in the form of observation sheets and test questions in the form of multiple choice learning outcomes. The data analysis technique used is qualitative and quantitative. From the results of the study concluded that: (1) Learning activities of students appear active in learning science in the application of articulation models assisted by visual media. Students play an active role during the learning process in cycle I. The results of observations of student activities are 3.52 with very active criteria, and (2) There is an increase in student learning outcomes after the application of articulation models assisted by visual media. This is indicated by the learning outcomes seen through the class average score in the first cycle, which is 79 with the criteria achieved and fulfilling the KKM 70, reaching the percentage of students' classical mastery learning, namely $100 \%$, with $85 \%$ classical completeness.

\section{Keywords: Articulation, Visual and Science Learning Outcomes, Learning Models.}

PENDAHULUAN

Pembelajaran mempunyai pengaruh yang sangat besar dalam membangun kognitif, afektif dan psikomotorik peserta didik, terutama untuk mengembangkan rasa percaya diri dalam berpendapat, bersosialisai dan menentukan cara untuk mencari tahu jawabannya. Oleh karena itu, peran model dan media pembelajaran sangat penting dalam meningkatkan aktivitas dan hasil belajar peserta didik pada pelajaran IPA.

Berdasarkan hasil Observasi hasil belajar IPA peserta didik kelas IV kurang dari $85 \%$ dimana sebagian besar memperoleh nilai dibawah Kriteria Ketuntasan Minimal (KKM) yang ditetapkan disekolah. Selain itu model dan media pembelajaran IPA yang digunakan guru masih kurang bervariasi, hal tersebut terlihat pada saat proses pembelajaran yang peneliti observasi, tentu saja akan mempengaruhi proses dan hasil belajar peserta didik pada mata pelajaran IPA dengan jumlah 27 orang peserta didik, menunjukkan bahwa terdapat $25 \%$ (9 orang peserta didik) mendapat nilai yang sudah dinyatakan ketuntasan belajar, sedangkan $75 \%$ (18 orang peserta didik) dinyatakan belum tuntas dalam pelajaran IPA. Untuk Kriteria ketuntasan (KKM) hasil belajar mata pelajaran IPA adalah 70. Pada proses pembelajaran guru tidak menggunakan media serta model pembelajaran yang digunakan masih kurang bervariasi. Sehingga membuat peserta didik menjadi kurang memperhatikan penjelasan guru pada saat pembelajaran berlangsung. Selain itu kurangnya pemahaman peserta didik terhadap pembelajaran Ilmu Pengetahuan Alam. disebabkan kurang optimalnya seorang guru dalam 
menerapkan penggunaan model pembelajaran sehingga mengakibatkan hasil belajar peserta didik dibawah standar yang telah ditentukan. Hal ini membuktikan bahwa tujuan pembelajaran IPA belum sepenuhnya tercapai sesuai nilai KKM.

Hasil belajar peserta didik kelas IV SDN 5 Panarung Palangka Raya yang berjumlah 27 orang, terdapat kurang lebih $75 \%$ atau 18 orang peserta didik yang nilainya masih dibawah Kriteria Ketuntasan Minimal (KKM), yaitu 70 dan hanya 9 orang peserta didik atau sekitar 25\% yang mencapai nilai Kriteria Ketuntasan Minimal (KKM) yang telah ditetapkan tersebut.

Berdasarkan permasalahan yang dikemukakan, baik aktivitas guru maupun peserta didik dan hasil belajar IPA terlihat masih kurang maksimal, akibatnya perlu adanya peningkatan kualitas pembelajaran IPA di SDN 5 Panarung Palangka Raya. Guru diharapkan mampu menggunakan Model Pembelajran dalam pembelajaran sehingga peserta didik tidak merasa jenuh dan bosan serta aktif dalam kegiatan pembelajaran. Salah satu strategi guru adalah dengan menggunakan model dan media pembelajaran yang melatih untuk bekerjasama dengan peserta didik lainnya dalam proses pembelajaran.

"Artikulasi merupakan salah satu model pembelajaran yang dapat Model pembelajaran Artikulasi merupakan model pembelajaran yang menuntut siswa untuk bisa berperan untuk sebagai "penerima pesan" sekaligus sebagai " penyampai pesan". pembelajaran yang telah diberikan guru, wajib diteruskan oleh siswa dan menjelaskannya kepada siswa lain didalam pasangan kelompoknya. Shoimin (2014:27). Sedangkan menurut Huda (2013:268)

Model pembelajaran artikulasi prosesnya seperti pesan berantai, artinya apa yang talah diberikan guru, seorang peserta didik wajid meneruskan atau menjalaskan pada peserta didik lainnya (teman kelompoknya)". Disinilah keunikkan model pembelajaran ini, peserta didik dituntut untuk bisa berperan sebagai penyampai pesan.model pembelajaran artikulasi merupakan model pembelajaran yang menuntut peserta didik untuk aktif dalam pembelajaran, dimana peserta didik dibentuk menjadi kelompok kecil yang masing-masing peserta didik dalamnya tersebut mempunyai tugas mewawancari teman sekelompoknya tentang materi yang baru dibahas

Berdasarkan penjelasan diatas, bahwa model pembelajaran Artikulasi adalah model seperti pesan berantai yang terdiri dari beberapa kelompok dan antar kelompok saling bertukar informasi dan yang penerima informasi terakhir akan menyampaikan apa yang telah didapatnya dari hasil pesan berantai tersebu. 
Suatu model pembelajaran memiliki kelebihan dan kekurangan. Kelebihan model pembelajaran Artikulasi dalam pembelajaran yaitu: 1 ) semua siswa terlibat. 2) melatih kesiapan siswa. 3) melatih daya serap atau pemehaman dari orang lain. 4) cocok untuk tugas sederhana. 5) interaksilebih mudah. 6) lebih mudah dan capat pembentukannya. 7) meningkatkan partisipasi anak. Selain memiliki kelebihan dalam pembelajarannya, model pembelajaran Artikulasi juga memiliki kekurangan dalam pembelajarannya yaitu: 1) hanya bisa diterapkan untuk mata pelajaran tertentu. 2) waktu yang dibutuhkan banyak. 3) materi yang didapat sedikit. 4) banyak kelompok yang melapor jadi perlu dimonitor. 5) lebih sedikit ide yang muncul

"Media Visual adalah media yang sangat memegang peran penting dalam proses pembelajaran dan dapat melancaekan pemahaman dan memperkuat ingatan. Menurut Arsyad (2013: 89). Sedangkan menurut Sudjana dan Riva (2011:8) menyatakan bahwa media Visual ialah tampilan atau lambang-lambang untuk memperjelas makna pesan yang dibicarakan dalam proses pembelajaran.

Menurut pendapat diatas bahwa media Visual ialah media yang hanya bisa menampilkan sebuah lambanglambang seperti gambar tanpa adanya suara dan gerak. Karena media ini memegang peran yang sangat penting untuk meningkatkan kemauan peserta didik untuk belajar.

Media visual memiliki kelebihan dan kekurangan, kelebihan media visual yaitu: 1) Sipatnya konkret, gambar lebih realita. 2) Gambar bisa mengatasi ruang dan waktu. 3) media gambar dapat mengatasi pengematan kita. 4) gambar dapat memperjelas suatu masalah. 5) peserta didik mudah memahaminya. 6) bisa menampilkan grafik, gambar dan diagram. 7) dapat dipergunakan dimanapun. 8) dapat dipergunakan tidak hanya satu orang. 9) dapat dipergunakan untuk memberikan umpan balik. Selain memiliki kelebihan dalam pembelajarannya media visual memiliki kekurangan yaitu: 1) lambat dan kurang praktis. 2) tidak ada audio sehingga kurang mendetail materi yang disampaikan. 3) visual terbatas hanya bisa memberikan gambar. 4) biaya produksi cukup mahal karena media cetak harus mencetak dan mengirimnya sebelum dapat dinukmati oleh masyarakat.

Penerapan model pembelajaran Artikulasi berbantuan media visual yaitu 1) Guru menyampaikan kompetensi dan tujuan yang ingin dicapai. 2) Guru menjelaskan materi pelajaran tentang "Dampak pengambilan bahan alam terhadap pelstarian lingkungan". 3) Guru menunjukan contoh jenis bahan alam yang berdampak pada pelestarian ingkungan dari media visual yang ada 
disekitar. 3) Guru membagi peserta didik dalam beberapa kelompok. 4) Guru membagikan lembar kerja Peserta didik 5) Setiap anggota kelompok berkerja sama mengerjakan. 6) Jika waktu pengerjaan soal sudah habis, siswa wajib mengumpulkan lembar jawaban kepada guru. 7) Guru memberikan reward kepada kelompok yang memperoleh jawaban paling banyak benar. Tujuan penerapan model pembelajaran Artikulai berbantuan media konkret ini yaitu untuk melatih peserta didik agar lebih cermat dan lebih kuat pemahamannya terhadap suatu materi pokok,saling menghargai pendapat teman, memunculkan ide dan melatih kesiapan dan daya serap peserta didik dari orang lain.

\section{METODE PENELITIAN}

Penelitian ini menggunakan rancangan metode Penelitian Tindakan Kelas (PTK), karena penelitian ini karena penelitian ini sedang berusaha untuk memecahkan atau menjawab permasalahan yang dihadapi pada situasi sekarang. Penelitian tindakan kelas adalah suatu penelitian tindakan yang bertujuan untuk memperbaiki atau meningkatkan mutu (kualitas) proses pembelajaran di dalam kelas, dilakukan oleh guru atau berkolaborasi dengan orang lain melalui tahapan perencanaan, tindakan, pengamatan, dan refleksi.

Peneliti hadir selama pelaksanaan penelitian di sekolah berlangsung. Peneliti juga berkolaborasi dengan guru mata pelajaran IPA di kelas IV. Peneliti berperan sebagai pengajar atau pelaksana tindakan, sedangkan guru mata pelajaran IPA berperan sebagai pengamat atau observer I, selain itu juga peneliti meminta bantuan dari 1 teman sejawat. Hal ini dilakukan untuk mendukung objektivitas hasil penelitian yang dilakukan oleh peneliti. Dalam pelaksanaan penelitian tindakan kelas ini yang menjadi subjek penelitian adalah peserta didik kelas IV yang berjumlah 27 orang. Terdiri dari 17 peserta didik laki-laki dan 10 peserta didik perempuan. Sedangkan yang menjadi objek penelitian adalah hasil belajar IPA. Pengumpulan data yang diperoleh pada penelitian ini dilakukan melalui pengamatan (observasi) dan tes hasil belajar. Penelitian ini menggunakan metode Penelitian Tindakan Kelas (PTK). Analisis data merupakan kegiatan yang dilakukan setelah data dari seluruh sumber terkumpul. Data yang telah dikumpulkan sebelumnya diolah menjadi dua jenis yaitu secara kualitatif dan kuantitatif. Data kualitatif diperoleh dari aktivitas terhadap peneliti dan aktivitas terhadap peserta didik dan respon peserta didik selama proses belajar mengajar dengan menganalisis hasil belajar yang dilihat dalam proses belajar mengajar menggunakan model pembelajaran Artikulasi berbantuan media visual. 
Data kuantitatif berasal dari hasil tes yang diberikan pada setiap akhir siklus kegiatan. Hal ini dilakukan untuk mengetahui peningkatan hasil belajar peserta didik pada pendekatan yang diterapkan.

\section{HASIL PENELITIAN}

Data hasil siklus pembelajaran dengan model pembelajaran Artikulasi berbatntuan media visual.

\begin{tabular}{|c|c|}
\hline 352 & 3,52 \\
\hline \multicolumn{2}{|l|}{2} \\
\hline \multicolumn{2}{|l|}{1} \\
\hline \multicolumn{2}{|r|}{ peserta didik } \\
\hline \multicolumn{2}{|c|}{$\begin{array}{l}\text { Gambar } 1 \text { Grafik Aktivitas Guru dan } \\
\text { Peserta Didik Pada Pembelajaran } \\
\text { Siklus I }\end{array}$} \\
\hline \multicolumn{2}{|c|}{$\begin{array}{l}\text { Tabel } 1 \\
\text { Data Aktivitas Guru dan peserta didik } \\
\text { Pada Siklus I }\end{array}$} \\
\hline \multicolumn{2}{|r|}{ Aktivitas } \\
\hline Guru & Peserta didik \\
\hline 3,73 & 3,52 \\
\hline
\end{tabular}

Dengan kriteria dan skor sebagai berikut:

$$
\begin{aligned}
& \text { Kurang Baik }=1-1,9 \\
& \text { Cukup Baik }=2-2,9
\end{aligned}
$$

$$
\begin{array}{ll}
\text { Baik } & =3-3,9 \\
\text { Sangat Baik } & =4
\end{array}
$$

Hasil belajar IPA peserta didik menggunakan model pembelajaran Artikulasi berbantuan media visual

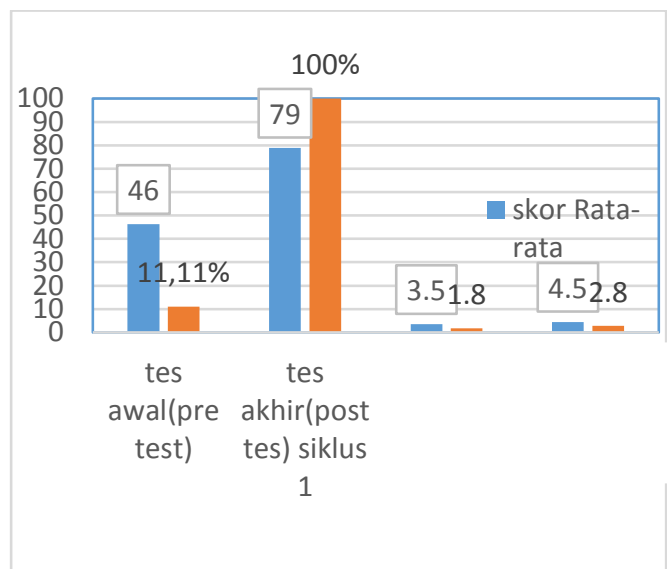

Gambar 2 Grafik Hasil Belajar Peserta Didik Pada Pembelajaran Siklus I

Berdasarkan tabel dan grafik diatas dapat disimpulkan bahwa ada peningkatan hasil belajar ilmu pengetahuan alam (IPA) peserta didik dengan menerapkan model pemeblajaran artkulasi berbantua media visual. pada tes awal (pre tes), hasil belajar peserta didik memperoleh skor rata-rata 46 dengan ketuntasan klasikal 11,11\%. Kemudian paa siklus I saat diberikan post tes hasil belajar peserta didik memperolehskor rata-rata 79 dan mencapai KKM 70, dengan ketuntasan klasikal $85 \%$. hal ini dapat disimpulkan bahwa model artikulasi berbantuan media visual dalam proses ilmu pengetahuan alam dapat membuat peserta didik lebih aktif saat proses 
pembelajaran berlangsung dan dapat meningkat hasil belajar peserta didik.

Penelitian ini bukan untuk membandingkan antar siklus tetapi peneliti memberikan perbandingan pada saat peneliti tidak mengajar dengan menerapkan model artkulasi berbantuan media visual yang tentunya menjadi faktor penyebab hasil belajar peserta didik meningkat.

\section{KESIMPULAN}

1. Aktivitas belajar peserta didik terlihat menjadi aktif dalam pembelajaran IPA pada penerapan model artikulasi berbantuan media visual di kelas IV di SDN 5 Panarung palangkaraya tahun pelajaran 2017/2018. peserta didik berperan aktif, termotivasi, saling berkerjasama selama proses pembelajaran berlangsung pada siklus I. Adapun hasil pengamatan aktivitas guru pada proses pembelajaran yang dilakukan oleh pengamat I dan pengamat II selama proses pembelajaran IPA pada siklus I rata-rata aspek aktivitas peserta didik yaitu 3,52 dengan kategori sangat baik.

2. Ada Peningkatan hasil belajar IPA peserta didik kelas IV di SDN 5 Panarung palangkaraya tahun pelajaran 2017/2018 setelah menerapkan model pembelajaran artikulasi berbantuan media visual.
Hal ini ditunjukkan dengan hasil belajar yang dilihat melalui skor rata-rata kelas pada tes awal yaitu 46 dan persentase ketuntasan klasikal 11,11\% dengan kriteria tidak tercapai. Pada siklus I skor rata-rata kelas yaitu 79 dan persentase ketuntasan belajar peserta didik secara klasikal yaitu $100 \%$, dari kriteria yang telah ditentukan yaitu untuk KKM adalah 70 dan kriteria ketuntasan secara klasikal adalah $85 \%$ dengan kategori tercapai. Dengan ini maka dapat disimpulkan bahwa ada peningkatan hasil belajar IPA peserta didik setelah menerapkan model pembelajaran artikulasi berbantuan media visual

\section{DAFTAR PUSTAKA}

Shoimin, Aris. (2014). 68 Model Pembelajaran Inovatif Dalam Kurikulum 2013. Jakarta: PT ARRUZZ MEDIA

Huda, Miftahul. (2013). Model-Model Pengajaran dan Pembelajaran. Jogyakarta: PT Pustaka Belajar Offset

Arsyad, Azhar. (2013). Media Pembelajaran. Jakarta: PT Raja Grafindo Persada

Sudjana \& Riva. (2011). Media Pembelajaran. Bandung: Sinar Baru Algensindo 